\section{Awareness of and Interest in Native Wildflowers among College Students in Plant- related Disciplines: A Case Study from Florida}

\author{
Hector Eduardo Pérez ${ }^{1,6}$, Carrie Reinhardt Adams ${ }^{1}$, \\ Michael E. Kane ${ }^{1}$, Jeffrey G. Norcini ${ }^{2,5}$, Glenn Acomb ${ }^{3}$, and \\ Claudia Larsen ${ }^{1,4}$
}

\begin{abstract}
AdDitional INDEX wORDs. attitudes, education, blindness, web-based survey
Summary. Traditional college students do not fit the demographic profile of people who are driving increased sales in gardening and landscaping or the use of native wildflowers. However, today's college students, especially those in plant-related disciplines, may be making future decisions regarding the use of native wildflowers for various applications. Many college students may be unaware of or disinterested in native wildflowers. We used a web-based survey to gauge awareness and interest of native wildflowers in Florida college students enrolled in plant-related disciplines. While students have a generally low awareness of native wildflowers, they expressed high levels of interest in learning more about the identification or cultivation of these species, seeing wildflowers, particularly on their campuses, and using wildflowers in different settings. Students were also interested in purchasing native wildflower seeds or finished plants from local retailers rather than through the Internet. We used student responses from this study to discuss education and marketing opportunities toward native wildflowers.
\end{abstract}

A visit to most retail horticulture operations reveals that marketing of gardening and landscaping goods is focused primarily on property and homeowners, which is understandable given that homeowners 35 to 69 years of age with annual incomes of $\$ 25,001$ to $\$ 100,000$ are the most active in gardening and landscaping (Butterfield, 2009; Kelley and Wehry, 2006; National Gardening Association, 2006). Moreover, interest by this segment of the market is likely to rise because of trends toward

\footnotetext{
This research was supported by the Florida Wildflower Foundation (grant no. E-007-07). We express our sincere gratitude to Dominique Ardura, Terry Zinn, Traci Irani, and all academic advisors or program directors involved. We thank Gary Knox and Mack Thetford and anonymous reviewers for constructive comments provided during preparation of this manuscript.

${ }^{1}$ University of Florida, Department of Environmental Horticulture, P.O. Box 110675, Gainesville, FL, 32611-0675.

${ }^{2}$ University of Florida, Department of Environmental Horticulture, North Florida Research and Education Center, Quincy, FL, 32351.

${ }^{3}$ University of Florida, Department of Landscape Architecture and The Program for Resource Efficient Communities, P.O. Box 32611-5704, Gainesville, FL, 32613-2667.

${ }^{4}$ Micanopy Wildflowers, Micanopy, FL 32667.

${ }^{5}$ Current address: OecoHort LLC, Tallahassee, FL, 32308-6222.

${ }^{6}$ Corresponding author. E-mail: heperez@ufl.edu.
}

increasing sales of gardening and landscaping products (Butterfield, 2009; Deneen and Gross, 2006); an aging populace that desires to create comfortable, safe, beautiful surroundings and spend time outdoors to appreciate nature (Clayton, 2007; Gräbnitz and Bokelmann, 2004; Hack and Zimmerman, 1996); personalization of home gardens and landscapes cyclical increases in property values (Hardy et al., 2000).

Paralleling the rise in gardening and landscaping interest is the rising demand and use of native plants (Brzuszek and Harkess, 2009; Brzuszek et al., 2007). For instance, the estimated sales value of native plants in Florida during 1997 was about \$106 million, by 2005 , sales reached about $\$ 316$ million (Hodges and Haydu, $2002,2006)$. Additionally, ecological landscape restoration and bioremediation tools for storm water management are expected to offer an enhanced opportunity for commercial applications beyond the residential market (G. Acomb, personal communication).

Indigenous, herbaceous, annual, and perennial wildflowers represent one component of native plant product choices. Typically, native wildflowers (Hack and Zimmerman, 1996); and are sold as seeds, although more popular species are provided as containerized material. The wildflower seed industry has experienced gains in popularity over the last 30 to 40 years and is considered to be a maturing, highly competitive market (Milstein, 2005). Native wildflower seeds are predominately used for revegetation, restoration, erosion control, and highway beautification programs (Harper-Lore and Wilson, 2000; Lowery, 1983; Milstein, 1989). However, seed firms have developed retail seed packets and other products such as "wildflower meadow in a can," aimed at homeowners. In other cases, pre-varietal indigenous or endemic wildflower germplasm has been evaluated for landscape performance, response to growth regulators, cultivation potential, and bred for important horticultural characteristics (Hammond et al., 2007; Harkess and Lyons, 1994a,1994b; Li and Zhou, 2005; Thomas and Schrock, 2004). Milstein (2005) contends that people living in developed countries and cooler, more temperate climates are more conscious of and interested in gardening with wildflowers, while there is less interest for wildflowers in subtropical and tropical climates. Nonetheless, methods for establishing native wildflowers at various spatial scales (e.g., home garden/landscape or large-scale projects) within subtropical climates have been established in response to growing interest in these species (Norcini, 2006; Norcini and Aldrich, 2004).

Traditional undergraduate and graduate students do not typically fit the demographic profile that is driving increased interest in gardening and landscaping or the use of wildflowers. For example, consumers $\geq 40$ years of age with a dual-income household and areas for gardening represented opportunities for Dutch bulb industry marketing programs, while younger consumers with limited knowledge of bulbs represented threats to market penetration (Hack and Zimmerman, 1996). Moreover, in our experiences teaching at all levels (i.e., freshman through graduate), we rarely encounter traditional college students who meet all the criteria of being homeowners, 35 to 69 years old, earn an average annual income of about $\$ 75,000$, and substantially invest what money and time they do 
have in gardening or landscaping. However, current college students, specifically those in horticulture or plant-related disciplines, are presumed to make future decisions regarding how and if native wildflowers will be used in educational programs, gardening, landscaping, or revegetation projects. Many college students may be unaware of or disinterested in native wildflowers for educational purposes, horticulture, or other applications.

We could not find published information regarding the levels of interest and attitudes toward wildflower education or use in students from other majors or regions; nor could we find comparisons between wildflowers and other horticultural crops in this segment of the population. Anecdotal evidence collected from informal polling with students enrolled in a college-level plant identification course revealed limited awareness of native wildflowers or their value (H.E. Pérez, unpublished data). This led us to hypothesize that college students within plant-related disciplines have little awareness and interest in native wildflowers. In this case study, our objective was to address this hypothesis by investigating the awareness, perceptions, and interest in native wildflowers among Florida college students enrolled in plant-related disciplines through a web-based survey.

\section{Materials and methods}

The survey instrument consisted of demographic questions pertaining to hometown postal code, college or university of enrollment, major area of study, age range, gender, and academic rank. Students were required to read a definition of Florida native wildflowers (FNWs) before proceeding to other questions. For the purposes of this survey, a FNW was defined as an herbaceous annual or perennial species that was growing in Florida before the arrival of $\mathrm{Co}^{-}$ lumbus to the new world, a common criterion for native species (Florida Native Plant Society, 2003). Respondents were then asked to rate their level of awareness of FNWs. Other questions related to wildflower awareness addressed the number of FNWs respondents could identify by name and sight, what season(s) they expected FNWs to be in bloom, and in what areas or ecosystems FNWs could be found. Next, respondents were queried regarding their knowledge about the ecological, aesthetic, and commercial value of FNWs. Finally, respondents were asked to provide their level of interest in experiencing FNWs in a variety of locations, becoming educated about FNWs, and purchasing FNWs. A three-, five-, or six-item Likert scale (e.g., yes $=1$, not sure $=2$, no $=3$ ) was used to categorize responses to questions dealing with awareness, value, and interest.

Originally, we were interested in surveying students enrolled in horticulture programs. However, because of the varied potential uses for native wildflowers, we expanded our sampling population to include students enrolled in plant-related majors. Twenty-eight universities or colleges within Florida were identified that offered 33 distinct plant-related majors (Table 1). Academic advisors or program directors from these majors within each school were identified via departmental websites. Contacts were e-mailed on 15 Sept. 2008 requesting that they direct students to the survey via an embedded hyperlink to the survey webpage, which was hosted by SurveyMonkey.com (SurveyMonkey. com, 2008). We selected this host for ease of use in designing the survey webpage, low-cost, privacy policy, and data collection and reporting capabilities (Dillman, 2000; Sills and Song, 2002; Solomon, 2001). A subsequent e-mail reminder was sent on 29 Sept. 2008. The survey remained open until 7 Oct. 2008. We estimated that 1067 students would need to respond to obtain a $95 \%$ confidence level with a confidence interval of \pm 3 (Ott and Longnecker, 2001). The actual response rate was about 134; representing a $95 \%$ confidence level with a confidence interval of \pm 8.5 . Low response rates represent consistent challenges for web-based surveys (Dillman and Bowker, 2001; Sills and Song, 2002; Fraze et al., 2003). Ott and Longnecker (2001) concede that self-administered surveys usually have the lowest response rates.

Excel 2007 (Microsoft, Redmond, WA) was used to generate frequencies, cross-classification tables for percentage comparison (Agresti and Finlay, 1986), and analyze the collected data. Comparison of responses between two groups was performed by calculating ridit scores and subjecting these to a two-sided Wilcoxon test for ordinal categorical distributions (Agresti and Finlay, 1986).

\section{Results}

Demographics. Eighty-six percent of respondents indicated that their hometown postal code was in Florida. Almost three-quarters of respondents were female $(72 \%)$, and the vast majority of students was 18 to 31 years old $(87 \%)$ (Table 2 ). Nearly all respondents (98\%) were in peninsular Florida (Table 2). Over half of all respondents $(52 \%)$ were enrolled in colleges or universities located in central Florida (e.g., Rollins College; University of South Florida, Tampa) or southern Florida (e.g., Florida Atlantic University, Florida International University, University of Miami). Roughly $46 \%$ of the respondents were enrolled at the University of Florida in northern Florida. Respondents from the other northern Florida colleges made up $2 \%$ of the sample. Students were enrolled in 14 plant-related degree programs. Most students were biology majors $(\approx 46 \%)$, followed by landscape architecture $(\approx 22 \%)$ and environmental science/studies $(\approx 10 \%)$. Less than $4 \%$ of respondents were enrolled in horticulture majors (i.e., environmental horticulture or golf and sports turf management). Two-thirds of respondents were undergraduate students, while Ph.D. students represented the smallest percentage $(\approx 12 \%)$ in academic rankings. Overall, about $24 \%$ and $21 \%$ of students identified themselves as senior undergraduate students and Master's degree candidates, respectively (Table 2 ).

AWARENES OF NATIVE WILDFLOWERS. About $52 \%$ of students indicated poor to fair awareness when self-reporting their general awareness of FNWs. Likewise, almost $55 \%$ of respondents would be able to identify only 0 to 4 FNWs if given their common and scientific names. However, $52 \%$ claimed the ability to identify 5 to 12 or more FNWs if supplied with pictures or live samples. Despite this shift, the distributions in number of FNWs that could be identified by name or sight were not statistically different (Table 3 ).

Students expected FNWs to bloom during the winter (3\%), spring $(31 \%)$, summer $(22 \%)$, fall (16\%), and 
Table 1. Florida universities and colleges offering plant-related majors. Programs of study within each major include curricula leading to undergraduate (U), Master's (MS), or Doctor of Philosophy (PhD) degrees. Program directors and advisors from each major were asked, via electronic mail, to direct students to a webpage that surveyed interest and awareness of Florida native wildflowers in enrolled in plant-related disciplines.

\begin{tabular}{|c|c|}
\hline University/college & Majors \\
\hline \multicolumn{2}{|l|}{ State university system } \\
\hline $\begin{array}{l}\text { Florida Agricultural and } \\
\text { Mechanical University }\end{array}$ & $\begin{array}{l}\text { Agribusiness }(\mathrm{U}) \text {, agricultural sciences }(\mathrm{MS}) \text {, agronomy }(\mathrm{U}) \text {, biological and agricultural } \\
\text { systems engineering }(\mathrm{U}) \text {, biology }(\mathrm{U}) \text {, entomology }(\mathrm{U}, \mathrm{PhD}) \text {, forestry and natural } \\
\text { resources conservation }(\mathrm{U}) \text {, landscape architecture }(\mathrm{MS}) \text {, landscape design and } \\
\text { management }(\mathrm{U}) \text {, ornamental horticulture }(\mathrm{U})\end{array}$ \\
\hline Florida Atlantic University & Biology (U, MS), ecology and organismic biology (U), environmental science (MS) \\
\hline Florida State University & Biological sciences (U, MS, PhD) \\
\hline New College & Biology (U), environmental studies (U) \\
\hline University of Central Florida & Biology (U, MS), conservation biology (PhD), environmental studies (U) \\
\hline University of Florida ${ }^{z}$ & $\begin{array}{l}\text { Agricultural and biological engineering, agricultural education and communication, } \\
\text { agricultural operations management, agronomy, botany, entomology and nematology, } \\
\text { environmental horticulture, environmental science, food and resource economics, } \\
\text { forest resources and conservation, landscape architecture, plant pathology, soil and } \\
\text { water science, wildlife ecology and conservation, zoology }\end{array}$ \\
\hline University of North Florida & Biology (U, MS) \\
\hline University of South Florida & Biology, including integrative biology (U, MS, PhD) \\
\hline University of West Florida & Biology (U, MS), environmental studies (U) \\
\hline \multicolumn{2}{|l|}{ Private liberal arts college ${ }^{y}$} \\
\hline Eckerd College & Biology, environmental studies \\
\hline Rollins College & Biology, environmental studies \\
\hline \multicolumn{2}{|l|}{ Public colleges ${ }^{x}$} \\
\hline Broward Community College & $\begin{array}{l}\text { Biology, botany, ecology, entomology, environmental science, forest resources and } \\
\text { conservation, horticultural science, zoology }\end{array}$ \\
\hline Chipola Community College & Natural science \\
\hline Edison Community College & Golf course operations \\
\hline Gulf Coast Community College & Pre-agriculture, pre-biology, pre-entomology, pre-environmental science, pre-forestry \\
\hline Palm Beach Community College & Biology, environmental horticulture, environmental science \\
\hline Pensacola Junior College & $\begin{array}{l}\text { Agricultural science, biology, environmental horticulture, forest technology, landscape } \\
\text { and horticulture management, natural resource conservation }\end{array}$ \\
\hline Santa Fe College & Biology \\
\hline South Florida Community College & Agriculture \\
\hline Tallahassee Community College & Natural science \\
\hline Valencia Community College & Horticultural science \\
\hline
\end{tabular}

${ }^{\mathrm{z} A l l}$ majors offer undergraduate and graduate degrees. Some majors have specializations. For example, environmental horticulture majors can specialize in golf and sports turf management.

'Only offer undergraduate degrees.

${ }^{\mathrm{x}}$ Community colleges offer 2-year degrees, while those listed as colleges may award 4-year degrees. No graduate programs are offered.

all seasons (29\%). Except for responses in the categories of dry sites, urban areas, and agricultural areas, greater than $72 \%$ of students responded yes when asked if FNWs occur in each type of area (Table 3 ). Within the categories of dry sites, urban areas, and agricultural areas, about $31 \%, 25 \%$, and $19 \%$ of students were not sure if FNWs occurred in these areas, and almost 19\% indicated that FNWs do not occur in urban areas.

S T U D E N T A G RE E M E N T REGARDING ECOLOGICAL, AESTHETIC, AND COMMERCIAL VALUE OF WILDFLOWERS. An overwhelming majority of students agreed or strongly agreed that FNWs along roadsides have ecological benefits $(\approx 94 \%)$ and are valuable to animals $(\approx 98 \%)$ or insects $(100 \%)$. However, there was less unanimity in terms of survival of wildflowers from areas outside of Florida [e.g., U.S. Department of Agriculture (USDA) cold hardiness zones $<8 \mathrm{a}]$ grown within the state (i.e., USDA cold hardiness zones 
Table 2. Demographic profile of Florida college student enrolled in plant-related majors and responding to questions related to their interest and awareness of Florida native wildflowers.

\begin{tabular}{|c|c|}
\hline Question & $\begin{array}{c}\text { Frequency } \\
\text { (no.) }\end{array}$ \\
\hline \multicolumn{2}{|l|}{ What is your hometown postal (zip) code? $(\mathrm{n}=134)$} \\
\hline Florida & 115 \\
\hline Non-Florida & 19 \\
\hline \multicolumn{2}{|c|}{ Which university or college are you currently enrolled in? $(\mathrm{n}=134)$} \\
\hline University of Florida & 61 \\
\hline University of Miami & 27 \\
\hline University of South Florida & 20 \\
\hline Rollins College & 10 \\
\hline Florida Atlantic University & 6 \\
\hline Florida International University & 6 \\
\hline Florida State University & 1 \\
\hline Lake City Community College & 1 \\
\hline Santa Fe Community College & 1 \\
\hline University of North Florida & 1 \\
\hline \multicolumn{2}{|l|}{ What is your degree program? $(\mathrm{n}=131)$} \\
\hline Biology & 60 \\
\hline Landscape architecture & 29 \\
\hline Environmental studies/science & 13 \\
\hline Ecology & 7 \\
\hline Natural resource conservation & 5 \\
\hline Golf and sports turf management & 4 \\
\hline Forestry (operations, resources, and conservation) & 3 \\
\hline Integrative biology & 3 \\
\hline Botany & 2 \\
\hline Conservation biology & 1 \\
\hline Ecosystem science and policy & 1 \\
\hline Environmental horticulture & 1 \\
\hline Wildlife ecology and conservation & 1 \\
\hline Zoology & 1 \\
\hline \multicolumn{2}{|l|}{ What is your age? $(\mathrm{n}=134)$} \\
\hline $18-21$ years & 58 \\
\hline $22-26$ years & 37 \\
\hline $27-31$ years & 22 \\
\hline $32-36$ years & 6 \\
\hline $37-41$ years & 6 \\
\hline$\geq 42$ years & 5 \\
\hline \multicolumn{2}{|l|}{ Your sex is? $(\mathrm{n}=134)$} \\
\hline Female & 96 \\
\hline Male & 38 \\
\hline \multicolumn{2}{|l|}{ What is your current classification? $(\mathrm{n}=132)$} \\
\hline Senior & 32 \\
\hline M.S. & 28 \\
\hline Junior & 20 \\
\hline Freshman & 19 \\
\hline Sophomore & 17 \\
\hline Ph.D. & 16 \\
\hline
\end{tabular}

$8 a-11)$. For example, $59 \%$ agreed or strongly agreed, while $41 \%$ disagreed that seeds of native wildflowers collected in other states would grow well in Florida. When asked if seeds of native wildflowers from other climates would grow well in Florida, about $34 \%$ agreed or strongly agreed, but 66\% disagreed (Table 4 ). of the students agreed or strongly agreed that FNWs remain green all year; the remainder disagreed with this statement. Nearly $60 \%$ of students disagreed that other states have prettier wildflowers than Florida, while almost $34 \%$ agreed.

LEVELS OF INTEREST IN SEEING OR USING WILDFLOWERS. Students expressed high levels of interest (i.e., about $77 \%-88 \%$ interest or great deal of interest) in seeing FNWs used along various types of transportation settings. The percentage of students who expressed neither interest nor disinterest ranged between about $10 \%$ and $21 \%$, and a very small percentage $(\geq 2.5 \%)$ expressed disinterest or a great deal of disinterest in seeing FNWs in these settings (Table 5). On the contrary, a higher level of interest (i.e., interest or great deal of interest) was expressed in seeing FNWs in leisure settings, including their campuses. This level ranged between $85 \%$ and about $97 \%$. Also, the range in percentage of students who were neither interested nor disinterested in seeing FNWs in leisure settings was about half that reported for transportation settings (Table 5 ).

Students conveyed high levels of interest for using FNWs not only in their landscapes $(\approx 83 \%)$ and gardens $(\approx 83 \%)$, but in commercial $(\approx 81 \%)$ and municipal government properties $(\approx 83 \%)$ as well (Table 6$)$. The range in percentage for those students who were neither interested nor disinterested in using FNWs in these types of settings was between $11 \%$ and $16 \%$. About $3 \%$ to $6 \%$ of students were disinterested in using FNWs in these locations (Table 6).

INTEREST LEVELS IN PURCHASING AND LEARNING MORE ABOUT WILDFLOwERs. Almost double the number of students indicated a high level of interest (i.e., interested and great deal of interest) in purchasing FNW seeds from local retailers $(\approx 71 \%)$ rather than using the Internet $(\approx 38 \%)$. The percentages were reversed for the remaining response variables. For example, about 19\% replied that they were neither interested nor disinterested in purchasing seeds from local retailers. However, this changed to about 36\% for Internet seed purchases. The collective level of disinterest (i.e., disinterested and great deal of disinterest) was almost three times greater for purchasing 
Table 3. Responses of Florida college students to questions related to awareness of Florida native wildflowers. A two-sided Wilcoxon test for ordinal categorical distributions was used to compare responses between name and sight identification of Florida native wildflowers. $\mathrm{Z}$ scores $(\mathrm{z}) \mathrm{P}>\mathbf{0 . 0 5}$ are not significantly different. The blooming season for 35 commercially available Florida native wildflowers for which information is readily available was included to gauge level of awareness in students.

\begin{tabular}{llc}
\hline Question & $\begin{array}{c}\text { Response } \\
\text { category }\end{array}$ & $\begin{array}{c}\text { Frequency } \\
\text { (no.) }\end{array}$ \\
\hline How would you rate & Excellent & 5 \\
your awareness of & Good & 29 \\
Florida native & Average & 28 \\
wildflowers? $(\mathrm{n}=129)$ & Fair & 31 \\
& Poor & 36
\end{tabular}

Frequency (no.)

If given a list showing their common and scientific names, how many Florida native wildflowers can you identify by name? $(\mathrm{n}=128)$

If given pictures or live samples, how many Florida native wildflowers can you identify by sight? $(\mathrm{n}=129)$

Which season or seasons of the year do you expect Florida native wildflowers to be in bloom? $(\mathrm{n}=129)$

Blooming season for commercially available wildflower species.

$(\mathrm{n}=35)$

\begin{tabular}{ccccc} 
Response category & Identify by name & Identify by sight & $\mathrm{Z}$ & $P$ \\
\hline$>12$ & 17 & 23 & -1.30 & 0.20 \\
$9-12$ & 10 & 15 & & \\
$5-8$ & 31 & 29 & & \\
$1-4$ & 54 & 48 & & \\
None & 16 & 14 &
\end{tabular}

Frequency (no.)

\begin{tabular}{lcc} 
Response category & Student response & Commercially available \\
\hline Winter & 4 & 2 \\
Spring & 40 & 6 \\
Summer & 28 & 14 \\
Fall & 20 & 12 \\
All & 37 & 1 \\
None & 0 & 0
\end{tabular}

Frequency (no.)

Are Florida native wildflowers found in the following areas? $(\mathrm{n}=126)$

\begin{tabular}{lrcr} 
Response category & Yes & Not sure & No \\
\hline Florida panhandle & 95 & 28 & 0 \\
North Florida & 100 & 23 & 1 \\
Central Florida & 110 & 15 & 1 \\
South Florida & 112 & 12 & 2 \\
The Florida Keys & 95 & 26 & 4 \\
Coastal habitats & 97 & 25 & 2 \\
Wetland habitats & 98 & 22 & 4 \\
Dry habitats & 79 & 38 & 7 \\
Urban areas & 68 & 31 & 23 \\
Rural areas & 112 & 12 & 1 \\
Suburban areas & 89 & 29 & 1 \\
Forested areas & 105 & 18 & 14 \\
Agricultural areas & 86 & 24 &
\end{tabular}

seeds over the Internet ( $\approx 27 \%$ ) compared with purchasing from local retailers $(\approx 10 \%)$ (Table 7 ).

The patterns in student interest levels for purchasing FNW plants from local retailers or the Internet were similar to seeds except that differences in high levels of interest or disinterest were greater. For example, nearly three times the number of students conveyed high levels of interest in purchasing FNW plants from local retailers $(\approx 77 \%)$ rather than over the Internet $(\approx 29 \%)$. About $21 \%$ and $33 \%$ were neither interested nor disinterested in purchasing FNW plants from local retailers or the Internet, respectively. However, roughly 21 times more students selected a high level of disinterest in purchasing FNW plants over the Internet $(\approx 38 \%)$ than from a local retailer $(\approx 2 \%)$. In both cases, there was highly significant evidence that the distributions for purchasing from local retailers or the Internet were different (Table 7).

A substantial percentage of respondents were also interested in taking classes or attending seminars on FNW identification ( $\approx 68 \%$ ) and establishment and maintenance in the landscape $(\approx 61 \%)$. However, about $19 \%$ of students indicated that they were disinterested or had a great deal of disinterest for either type of learning opportunity. There was no 
Table 4. Florida college students' level of agreement with statements regarding ecological factors, aesthetics, and use of Florida native wildflowers (FNWs).

\begin{tabular}{|c|c|c|c|c|c|}
\hline \multirow[b]{2}{*}{ Statements } & \multicolumn{5}{|c|}{ Frequency (no.) } \\
\hline & $\begin{array}{l}\text { Strongly } \\
\text { agree }\end{array}$ & Agree & $\begin{array}{c}\text { Neither agree } \\
\text { or disagree }\end{array}$ & Disagree & $\begin{array}{l}\text { Strongly } \\
\text { disagree }\end{array}$ \\
\hline \multicolumn{6}{|l|}{ Ecological focus } \\
\hline FNWs growing along roadsides have ecological benefits. $(n=120)$ & 67 & 46 & 0 & 7 & 0 \\
\hline FNWs are valuable to animals. $(\mathrm{n}=121)$ & 91 & 27 & 0 & 3 & 0 \\
\hline $\begin{array}{l}\text { FNWs are valuable to many insects, including bees and } \\
\text { butterflies. }(n=121)\end{array}$ & 107 & 14 & 0 & 0 & 0 \\
\hline $\begin{array}{l}\text { Seeds of native wildflowers from other climates will grow } \\
\text { well in Florida. }(n=120)\end{array}$ & 4 & 37 & 0 & 79 & 0 \\
\hline \multicolumn{6}{|l|}{ Aesthetic focus } \\
\hline FNWs have aesthetic value. $(\mathrm{n}=121)$ & 92 & 27 & 0 & 2 & 0 \\
\hline FNWs have showy flowers. $(\mathrm{n}=120)$ & 38 & 62 & 0 & 20 & 0 \\
\hline FNWs can be planted in commercial areas. $(n=121)$ & 72 & 45 & 0 & 4 & 0 \\
\hline FNW seeds are readily available for purchase. $(n=120)$ & 24 & 58 & 0 & 38 & 0 \\
\hline FNWs are difficult to maintain in the landscape. $(n=119)$ & 6 & 21 & 0 & 92 & 0 \\
\hline $\begin{array}{l}\text { Local government agencies plant wildflowers along roadsides } \\
\text { in Florida. }(n=121)\end{array}$ & 21 & 55 & 0 & 45 & 0 \\
\hline $\begin{array}{l}\text { The state of Florida uses wildflowers along roadways and } \\
\text { highways. }(n=120)\end{array}$ & 30 & 60 & 0 & 30 & 0 \\
\hline
\end{tabular}

Table 5. Florida college students' level of interest in seeing Florida native wildflowers (FNWs) in various settings.

\begin{tabular}{|c|c|c|c|c|c|}
\hline \multirow[b]{2}{*}{ Statements } & \multicolumn{5}{|c|}{ Frequency (no.) } \\
\hline & $\begin{array}{l}\text { Great deal } \\
\text { of interest }\end{array}$ & Interested & $\begin{array}{l}\text { Neither interested } \\
\text { nor disinterested }\end{array}$ & Disinterested & $\begin{array}{c}\text { Great deal } \\
\text { of disinterest }\end{array}$ \\
\hline \multicolumn{6}{|l|}{ Transportation focus } \\
\hline Seeing FNWs along local roadsides. $(n=120)$ & 78 & 27 & 13 & 1 & 1 \\
\hline $\begin{array}{l}\text { Seeing FNWs along local or suburban } \\
\text { medians. }(\mathrm{n}=120)\end{array}$ & 78 & 28 & 12 & 1 & 1 \\
\hline $\begin{array}{l}\text { Seeing FNWs along other transportation } \\
\text { corridors. }(n=119)\end{array}$ & 65 & 27 & 15 & 1 & 1 \\
\hline \multicolumn{6}{|l|}{ Leisure focus } \\
\hline Seeing FNWs in parks. $(\mathrm{n}=119)$ & 93 & 22 & 2 & 2 & 0 \\
\hline Seeing FNWs in natural areas. $(\mathrm{n}=119)$ & 98 & 16 & 3 & 2 & 0 \\
\hline $\begin{array}{l}\text { Seeing FNWs at highway rest stops. } \\
\qquad(\mathrm{n}=120)\end{array}$ & 77 & 25 & 13 & 4 & 1 \\
\hline
\end{tabular}

statistical difference in the distribution of interest levels for classes on FNW identification or cultivation (Table 7).

\section{Discussion}

Respondents in this study were not typical of the demographic profile that has driven increases in gardening and landscaping or the use of native plants in these activities. However, more female students took part in the survey than males. This type of response mirrors the general trend that females are more involved in gardening or interested in learning about plants than males (National Gardening Association, 2006; Wandersee and Schussler, 1999). Most of the respondents were from majors outside of horticulture (Table 2). Despite this, there may be opportunities for horticulture departments to draw in students of different academic ranks from various majors given the poor to fair awareness of native wildflowers. These students also proved to have very high levels of interest in seeing native wildflowers on their campuses (Table 5 ) and using native wildflowers themselves, as well as a perception of high aesthetic value and preference for learning about identification and 
Table 6. Florida college students' level of interest in using Florida native wildflowers (FNWs) in various landscaping settings.

\begin{tabular}{lcccc}
\hline & \multicolumn{3}{c}{ Frequency (no.) } \\
\cline { 2 - 5 } Statements & $\begin{array}{c}\text { Great deal } \\
\text { of interest }\end{array}$ & $\begin{array}{c}\text { Neither interested } \\
\text { Interested } \\
\text { nor disinterested }\end{array}$ & $\begin{array}{c}\text { Great deal } \\
\text { Disinterested } \\
\text { of disinterest }\end{array}$ \\
\hline Using FNWs in my home landscape. $(\mathrm{n}=120)$ & 70 & 30 & 15 & 5 \\
Using FNWs in my home garden. $(\mathrm{n}=120)$ & 63 & 37 & 13 & 0 \\
Using FNWs at commercial properties. $(\mathrm{n}=120)$ & 66 & 31 & 19 & 7 \\
Using FNWs at municipal government & 71 & 28 & 16 & 4 \\
$\quad$ buildings. $(\mathrm{n}=120)$ & & & 5 \\
\hline
\end{tabular}

Table 7. Florida college student responses related to level of interest in purchasing Florida native wildflower (FNW) seeds and finished plants from local retailers or over the Internet and becoming educated about wildflower identification or cultivation. A two-sided Wilcoxon test for ordinal categorical distributions was used to compare responses between retail environments or educational topics. $\mathrm{Z}$ scores $(\mathrm{z})$ at $P>\mathbf{0 . 0 5}$ are not significantly different.

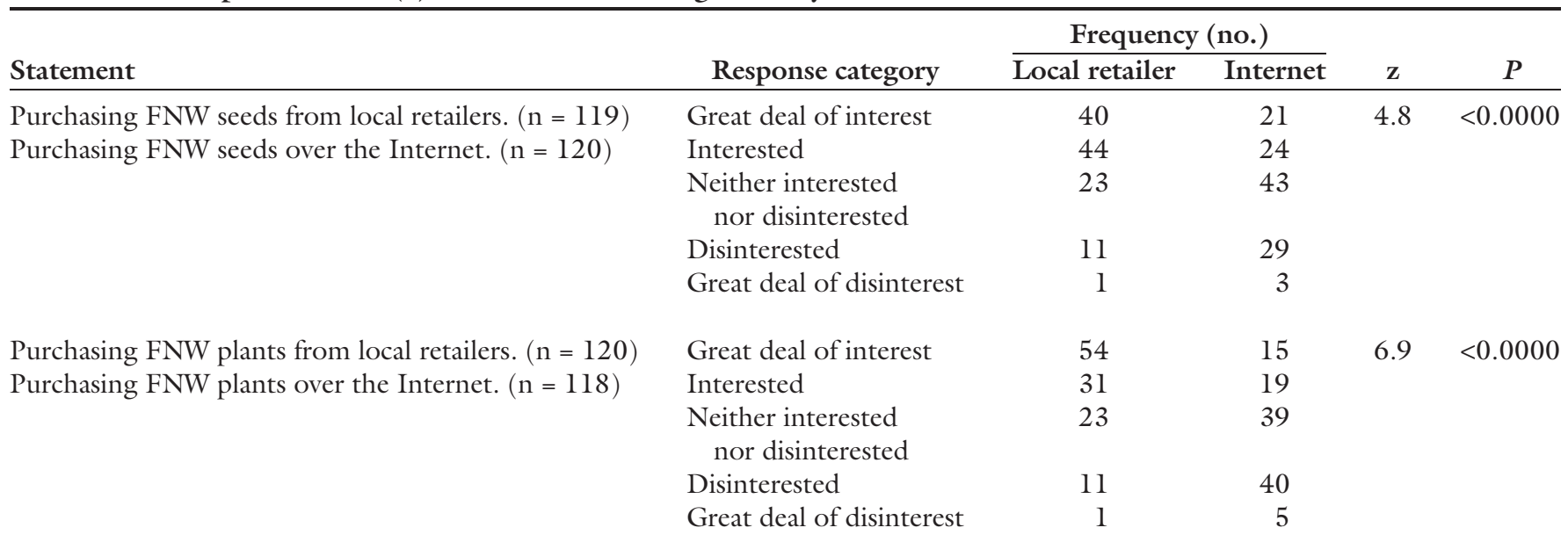

\begin{tabular}{|c|c|c|c|c|c|}
\hline & & Identification & $\begin{array}{l}\text { Establishment } \\
\text { and maintenance }\end{array}$ & $\mathbf{z}$ & $P$ \\
\hline \multirow{2}{*}{$\begin{array}{l}\text { Taking classes or attending seminars on } \\
\text { wildflower identification. }(n=120)\end{array}$} & Great deal of interest & 35 & 35 & \multirow[t]{4}{*}{0.6} & \multirow[t]{4}{*}{0.6} \\
\hline & Interested & 47 & 38 & & \\
\hline \multirow{2}{*}{ maintenance in the landscape. $(\mathrm{n}=120)$} & Disinterested & 20 & 18 & & \\
\hline & Great deal of disinterest & 3 & 5 & & \\
\hline
\end{tabular}

cultivation of these species-all of these factors can be incorporated into horticultural education programs. This is particularly relevant as plant science programs continue to experience decreasing or flat enrollment (Darnell and Cheek, 2005; McCallister et al., 2005; Rhodus, 1990) and face pressure to bring in more students.

Although students were able to identify areas where FNWs occur with little trouble and claimed to be able to identify by sight a good number of FNWs, their ability to accurately identify flowering season for FNWs was skewed compared with reported flowering season (Table 2; Bell and Taylor, 1982; Taylor, 1998; Wildflower
Seed and Plant Growers Association, 2003). Moreover, when asked if FNWs occur in dry sites, over onethird of the students did not know or denied that FNWs occurred in this type of area. In Florida, characteristically dry ecosystems such as prairies, scrubby flatwoods, high pinelands, sand hills, scrub, and rocklands host a large proportion of native herbaceous wildflower species (Bell and Taylor, 1982; Myers and Ewel, 1990; Taylor, 1998). Also, many students consider FNWs to be absent from urban settings, suggesting that more can be done to incorporate these species in urban horticulture programs.
The poor to fair awareness of native wildflowers self-reported in this group of college students is not so surprising. First, unlike the mature wildflower seed industry in regions such as the Pacific northwestern U.S., California, midwestern U.S., or northeastern U.S. (Milstein, 2005), Florida's wildflower seed industry is still emerging. Thus, efforts at marketing FNW seeds and plants to the general public are still evolving. Next, although some states mandate plant science curriculum in primary and secondary schools, these efforts may be limited due to inadequate teacher training, resources, or time spent on preparing for assessment tests (Lamb 
and Neal, 2005). We found no evidence of curriculum tools or teacher training that dealt with FNWs on state-level agriculture department education websites or state-level education department websites addressing statewide teaching standards (Florida Department of Agriculture and Consumer Services, 2004, 2009; Florida Department of Education, 2005). Moreover, there is a wide-spread perceptual disconnect between humans and the botanical world. This has been described as "plant blindness" in teachers and students (Wandersee and Schussler, 2001). Therefore, as most students move through the educational system, it is unlikely that they are exposed to plants, specifically native wildflowers, in the curriculum. Despite this, some effort is being made to educate grade school students about FNWs (Norcini et al., 1997), including an education grant program funded by the Florida Wildflower Foundation (2009). It is not yet known how these early educational efforts will translate into knowledge of FNWs during the college years.

The very high perceived value of FNWs in these students is another attribute that perhaps can be incorporated by educators. For example, students expressed high ecological value for FNWs. However, about $60 \%$ of students agreed or strongly agreed that seeds of native wildflowers from other states would grow well in Florida and about $34 \%$ agreed or strongly agreed that seeds of wildflowers from other climates would grow well in Florida. This reflects a significant misconception, as wildflowers from hardiness zones outside of Florida do not perform as well within the state as Florida ecotypes (Marois and Norcini, 2003; Norcini et al., 1998, 2001). Lessons on ecotypic variation, provenance, or scheduling of locally and non-locally adapted germplasm in horticultural production would be particularly appropriate.

Students also expressed very high interest in purchasing FNWs as seeds or finished material, representing an opportunity for the wildflower industry, especially in Florida. The retail environment seems to be remarkably important; students would prefer to purchase seeds or plants from local retailers rather than through the Internet by an overwhelming majority.
In conclusion, Florida college students in plant-related disciplines generally displayed low awareness of FNWs. Despite this lack of knowledge, students reported wanting to see, use, purchase, or learn more about these species. Therefore, an opportunity exists for educators and the industry to couple this enthusiasm for wildflowers with multiple experiences in wildflower education and exposure. Possible educational opportunities include using wildflowers to teach about morphological features in plant identification courses; plant phenology in biology or ecology courses; or sexual reproduction, seed production, seed dormancy/ germination, and plug production in propagation courses. Another useful educational experience is in field activities that involve hands-on cultivation and management of FNWs in the landscape or restoration settings. Moreover, educators could consider using wildflowers as part of elective courses, such as in floral arranging or in large-scale introductory courses intended to interest students in particular majors. Such efforts can influence future decision makers and are likely to benefit the native wildflower market.

\section{Literature cited}

Agresti, A. and B. Finlay. 1986. Statistical methods for the social sciences. Dellen Publishing, San Francisco.

Bell, C.R. and B.J. Taylor. 1982. Florida wildflowers and roadside plants. Laurel Hill Press, Chapel Hill, NC.

Brzuszek, R.F. and R.L. Harkess. 2009. Green industry survey of native plant marketing in the southeastern United States. HortTechnology 19:168-172.

Brzuszek, R.F., R.L. Harkess, and S.J. Mulley. 2007. Landscape architects' use of native plants in the southeastern United States. HortTechnology 17:7881 .

Butterfield, B. 2009. Strong lawn and garden sales expected for 2009. 28 July 2009. <http://www.garden.org/articles/ articles.php?q=show\&id $=3193>$.

Clayton, S. 2007. Domesticated nature: Motivations for gardening and perceptions of environmental impact. J. Environ. Psychol. 27:215-224.

Darnell, R.L. and J.G. Cheek. 2005. Plant science graduate students: Demographics, research areas, and recruitment issues. HortTechnology 15:677-681.

Deneen, M.A. and A.C. Gross. 2006. The U.S. market for power lawn and garden equipment. Bus. Econ. (April):62-67.

Dillman, D.A. 2000. Mail and Internet surveys: The tailored design method. Wiley, New York.

Dillman, D.A. and D.K. Bowker. 2001. The web questionnaire challenge to survey methodologists, p. 159-178. In: U. Reips and M. Bosnjak (eds.). Dimensions of internet science. Pabst Science Publishers, Lengerich, Germany.

Florida Department of Agriculture and Consumer Services. 2004. Florida Department of Agriculture and Consumer Services. 24 Aug. 2009. <http:// www.doacs.state.fl.us/>.

Florida Department of Agriculture and Consumer Services. 2009. Florida Agriculture in the Classroom, Inc. 24 Aug. 2009. <http://www.flagintheclassroom. com/index.html $>$.

Florida Department of Education. 2005. DOE home. 9 Sept. 2009. <http:// www.fldoe.org/default.asp $>$.

Florida Native Plant Society. 2003. Definition of a "Florida native plant." 11 Nov. 2009. <http://www.fnps.org/ pages/plants/defintion.php $>$.

Florida Wildflower Foundation. 2009. Grant program. 9 Sept. 2009. <http:// floridawildflowerfoundation.org/ grant_application.html>.

Fraze, S.D., K.K. Hardin, M.T. Brashears, J.L. Haygood, and J.H. Smith. 2003. The effects of delivery mode upon survey response rate and perceived attitudes of Texas agri-science teachers. J. Agr. Educ. $44: 27-37$.

Gräbnitz, D. and W. Bokelmann. 2004. Trends and tendencies: How experts of the horticultural sector expect business environment in the future. Acta Hort. 655:225-232.

Hack, M.D. and K.L. Zimmerman. 1996. Product differentiation strategies based on trends in the market. Acta Hort. 429:423-429.

Hammond, H.E., R.K. Schoellhorn, S.B. Wilson, and J.G. Norcini. 2007. Differing blanketflower cultivar and ecotype responses to plant growth regulators. HortTechnology 17:552-556.

Hardy, J., B.K. Behe, S.S. Barton, T.J. Page, R.E. Schutzki, K. Muzii, R.T. Fernandez, M.T. Haque, J. Brooker, C.R. Hall, R. Hinson, P. Knight, R. McNeil, D.B. Rowe, and C. Safley. 2000. Consumers preferences for plant 
size, type of plant material and design sophistication in residential landscaping. J. Environ. Hort. 18:224-230.

Harkess, R.L. and R.E. Lyons. 1994a. Gibberellin- and cytokinin-induced growth and flowering responses in $R u d$ beckia hirta L. HortScience 29:141-142.

Harkess, R.L. and R.E. Lyons. 1994b. Rudbeckia birta L.: A versatile North American wildflower. HortScience 29:134-227.

Harper-Lore, B. and M. Wilson (eds.). 2000. Roadside use of native plants. Island Press, Washington, DC.

Hodges, A.W. and J.J. Haydu. 2002. Economic impacts of the Florida environmental horticulture industry, 2000. Inst. Food Agr. Sci., Univ. Florida, Gainesville.

Hodges, A.W. and J.J. Haydu. 2006. Economic impacts of the Florida environmental horticulture industry in 2005. Inst. Food Agr. Sci., Univ. Florida, Gainesville.

Kelley, K.M. and R.H. Wehry. 2006. Consumer interest in gardening topics and preferred information sources. J. Ext. 44(2). 24 Aug. 2009. <http:// www.joe.org/joe/2006april/rb7.php>.

Lamb, E. and A. Neal. 2005. Cultivating young minds: Using a plant science workbook to interest grade school students in horticulture as a career. Acta Hort. 672:191-196.

Li, X.X. and Z.K. Zhou. 2005. Endemic wild ornamental plants from northwestern Yunnan, China. HortScience 40:1612-1619.

Lowery, C.A. 1983. Wild flowers: An aesthetic way of conserving water and fuel in Florida. Proc. Florida State Hort. Soc. 96:178-180.
Marois, J.J. and J.G. Norcini. 2003. Survival of black-eyed susan from different regional seed sources under low and high input systems. HortTechnology 13:161165.

McCallister, D.L., D.J. Lee, and S.C. Mason. 2005. Student numbers in agronomy and crop science in the United States: History, current status, and possible actions. North American Colleges Teachers Agr. J. 49:24-29.

Milstein, G.P. 2005. The uses and potential of wildflower seed in landscaping, $\mathrm{p}$. 39-51. In: M.B. McDonald and F.Y. Kwong (eds.). Flower seeds biology and technology. CABI, Wallingford, UK.

Myers, R.L. and J.J. Ewel (eds.). 1990. Ecosystems of Florida. University Press of Florida, Gainesville, FL.

National Gardening Association. 2006. What gardener's think. Harris Interactive, South Burlington, VT.

Norcini, J.G. 2006. Establishing a small planting of native wildflowers from seed. Inst. Food Agr. Sci., Univ. Florida Rpt. ENH1046.

Norcini, J.G. and J.H. Aldrich. 2004. Establishment of native wildflower plantings by seed. Inst. Food Agr. Sci., Univ. Florida Rpt. ENH968.

Norcini, J.G., J.H. Aldrich, L.A. Halsey, and J.G. Lilly. 1998. Seed source affects performance of six wildflower species. Proc. Florida State Hort. Soc. 111:4-9.

Norcini, J.G., L.A. Halsey, and J.G. Lilly. 1997. Preservation of local ecotypes: Final report. Contract 96049. Florida Advisory Council on Environmental Education, Tallahassee, FL.

Norcini, J.G., M. Thetford, K.A. KlockMoore, M.L. Bell, B.K. Harbaugh, and
J.H. Aldrich. 2001. Growth, flowering, and survival of black-eyed susan from different regional seed sources. HortTechnology 11:26-30.

Ott, R.L. and M. Longnecker. 2001. Statistical methods and data analysis. 5th ed. Duxbury Press, Pacific Grove, CA.

Rhodus, W.T. 1990. Analysis of recent enrollment trends and recruiting strategies in horticulture. HortScience 25:1443-1446.

Sills, S.J. and C. Song. 2002. Innovations in survey research. Soc. Sci. Comput. Rev. 20:22-30.

Solomon, D.J. 2001. Conducting webbased surveys. Practical Assessment Res. Evaluation 7(19). 11 Nov. 2009. <http:// PAREonline.net/getvn.asp? $\mathrm{v}=7 \mathrm{n}=19>$.

SurveyMonkey.com. 2008. SurveyMonkey. I Oct. 2008. <http://www.surveymonkey. com/Default.aspx>.

Taylor, W.K. 1998. Florida wildflowers in their natural communities. University Press of Florida, Gainesville, FL.

Thomas, A.L. and D. Schrock. 2004. Performance of 67 native midwestern U.S. perennials in a low-maintenance landscape. HortTechnology 14:381-388.

Wandersee, J.H. and E.E. Schussler. 1999. Preventing plant blindness. Amer. Biol. Teach. 61:82-86.

Wandersee, J.H. and E.E. Schussler. 2001 . Toward a theory of plant blindness. Plant Sci. Bul. 47:2-9.

Wildflower Seed and Plant Growers Association. 2003. Seed availability. 21 Aug. 2009. <http://www.floridawildflowers. com/seed.htm>. 